\title{
Halogen-containing thiazole orange analogues - new fluorogenic DNA stains
}

\author{
Aleksey A. Vasilev ${ }^{*}$, Meglena I. Kandinska ${ }^{2}$, Stanimir S. Stoyanov², \\ Stanislava B. Yordanova ${ }^{2}$, David Sucunza ${ }^{3}$, Juan J. Vaquero ${ }^{3}$, Obis D. Castaño ${ }^{3}$, \\ Stanislav Baluschev ${ }^{4}$ and Silvia E. Angelova*3,5
}

\section{Full Research Paper}

\section{Address:}

${ }^{1}$ Department of Pharmaceutical and Applied Organic Chemistry, Faculty of Chemistry and Pharmacy, Sofia University "St. Kliment Ohridski”, 1 James Bourchier Blvd., 1164 Sofia, Bulgaria, 2Department of Organic Chemistry and Pharmacognosy, Faculty of Chemistry and Pharmacy, Sofia University "St. Kliment Ohridski", 1 James Bourchier Blvd., 1164 Sofia, Bulgaria, ${ }^{3}$ Departments of Organic and Physical Chemistry, University of Alcala, 28871-Alcala de Henares, Madrid, Spain, ${ }^{4}$ Max Planck Institute for Polymer Research, Ackermannweg 10, 55128 Mainz, Germany and ${ }^{5}$ Institute of Organic Chemistry with Centre of Phytochemisty, Bulgarian Academy of Sciences, 1113 Sofia, Bulgaria (permanent address)

\section{Email:}

Aleksey A. Vasilev* - ohtavv@chem.uni-sofia.bg; Silvia E. Angelova* sea@orgchm.bas.bg

* Corresponding author

\section{Keywords:}

cyanine dyes; DFT calculations; green synthesis; nucleic acids; thiazole orange

\author{
Beilstein J. Org. Chem. 2017, 13, 2902-2914. \\ doi:10.3762/bjoc. 13.283
}

Received: 01 August 2017

Accepted: 15 December 2017

Published: 28 December 2017

Associate Editor: K. N. Allen

(C) 2017 Vasilev et al.; licensee Beilstein-Institut.

License and terms: see end of document.

\footnotetext{
Abstract

Novel asymmetric monomeric monomethine cyanine dyes $\mathbf{5 a}-\mathbf{d}$, which are analogues of the commercial dsDNA fluorescence binder thiazole orange (TO), have been synthesized. The synthesis was achieved by using a simple, efficient and environmetally benign synthetic procedure to obtain these cationic dyes in good to excellent yields. Interactions of the new derivatives of TO with dsDNA have been investigated by absorption and fluorescence spectroscopy. The longest wavelength absorption bands in the UV-vis spectra of the target compounds are in the range of 509-519 $\mathrm{nm}$ and these are characterized by high molar absorptivities $\left(63000-91480 \mathrm{~L} \cdot \mathrm{mol}^{-1} \cdot \mathrm{cm}^{-1}\right)$. All investigated dyes from the series are either not fluorescent or their fluorescence is quite low, but they become strongly fluorescent after binding to dsDNA. The influence of the substituents attached to the chromophores was investigated by combination of spectroscopic (UV-vis and fluorescence spectroscopy) and theoretical (DFT and TDDFT calculations) methods.
} 


\section{Introduction}

Since the discovery by Lee and co-workers $[1,2]$ that the old photographic dye thiazole orange, TO, (Scheme 1) has excellent properties as a fluorogenic noncovalent DNA or RNA binder, many representatives of this class of dyes have been developed [3-7].

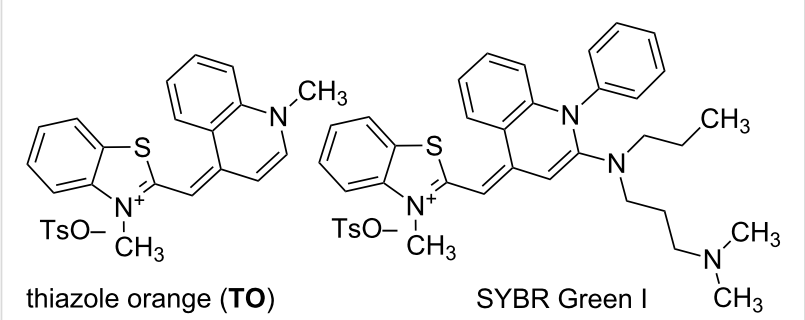

Scheme 1: Chemical structures of TO and SYBR Green I - commercial monomethine fluorescent dsDNA binders.

Thiazole orange does not fluoresce in the free state in solution. Fluorescence appears when the rotation about the monomethine bridge between the two heterocyclic moieties is somehow limited [5-7]. Such a restriction occurs when TO derivatives bind to nucleic acids by intercalation between the base pairs $[6,8]$ or presumably between individual bases in single-stranded nucleic acids and in both cases a dramatic increase of the fluorescence is observed. The valuable properties as nucleic acid stains have made these dyes an irreplaceable tool in the active and developing area of bioanalytical chemical research $[9,10]$. Cyanine dyes have found various bioanalytical applications as soluble DNA intercalators (e.g., in living cell imaging [11] and flow cytometry $[12,13]$, DNA fragment sizing [14,15], as reporter groups in hybridization probes [16-23], single DNA molecule fluorescence microscopy [24,25], gel staining [26], in real-time PCR analysis $[27,28]$ ) because of their excellent staining properties. Unsymmetrical cyanines have been conjugated to a variety of molecules, including peptides [29], proteins [30], DNA [17], and DNA analogues such as peptide nucleic acid (PNA) [16,31]. TO-based chromophores assembled as a structural scaffold inside nucleic acids (TO-tethered nucleic acids) have attracted considerable attention [32]. Hybridization-sensitive fluorescent probes in which TO is tethered to a nucleic acid: DNA [22,23,33-36], RNA [20,36] or
PNA $[18,19,21,31])$ strands have been constructed by several research groups (the Krull, Kubista, Seitz and Wagenknecht groups). The continued scientific and commercial interest in the preparation and application of cyanine dyes as bio-probes $[37,38]$ and our research in this area [39-41] has led us to search for novel representatives of this interesting family of compounds. The main goal of the study described here was to investigate the influence of different halogen atoms (connected directly to the chromophore or as side groups) on the molar absorptivity and the fluorescence intensity of a series of new TO analogues. Photophysical properties of a series of TO analogues that have fluoro- or trifluoromethyl groups connected to the heterocyclic end groups of the chromophores have been studied by Armitage and co-workers [42,43]. According to these studies the fluorination of the symmetrical [42] and unsymmetrical [43] cyanine dyes results in reduced aggregation and significantly improved the photostability and photophysical properties of the dyes.

The authors [43] used an interesting modification of Brooker's method (Scheme 2) for the synthesis of the fluorinated TO analogues but they obtained the target compound in very low overall yield. Generally, symmetric or unsymmetric monomethine cyanine dyes can be synthesized by the method of Brooker et al. $[44,45]$ using a condensation reaction between 2-methylthiobenzothiazolium salts with 1-alkyl-4-methylquinolinium salts.

Although Brooker's synthetic approach usually provides high reaction yields and has very low costs, the method suffers from serious disadvantages. One of these is the possibility of interchange of the alkyl groups at the thioalkyl unit and nitrogen atom in the quaternized 2-alkylthio starting materials, which leads to unexpected reaction products $[45,46]$. The other major disadvantage is the evolution of methylmercaptan - a toxic pollutant with a very unpleasant odor.

\section{Results and Discussion Synthesis of intermediates and dyes}

On the basis of Green Chemistry concepts [47-49] and with the aim of avoiding the disadvantages of Brooker's method and

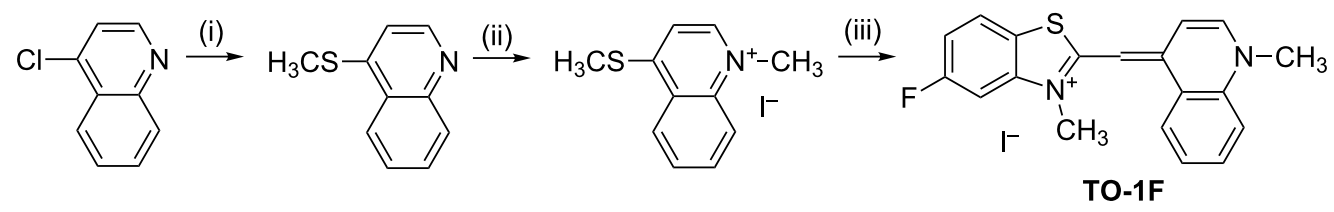

Scheme 2: Synthesis of the monofluoro-substituted dye TO-1F. Reagents, conditions and yields: (i) sodium methanethiolate $\left(\mathrm{NaSCH}_{3}\right), 7 \mathrm{~h}$, reflux; (ii) methyl iodide, overnight, overall yield for (i) and (ii) $9 \%$; (iii) 5-fluoro-2,3-dimethylbenzothiazolium iodide and triethylamine, rt, overnight, yield $24 \%$. 
reducing the adverse effects of the synthesis, we report here a simple, environmentally more benign (in comparison the Brooker's method), and efficient synthetic procedure. The method started with the quaternization of all starting materials (Scheme 3), which was performed in a sealed tube under an argon atmosphere to prevent possible side reactions like oxidation of the corresponding $\mathrm{N}$-containing heterocylic intermediates or self-condensation of the resulting quaternary products. Carrying out the reaction in bulk without solvents allows scaleup of the quaternary salt synthesis and prevents possible environmental pollution. The known synthetic procedure [50,51] for the target dyes (Scheme 3 ) was modified to obtain the model compound TO-7Cl. The condensation of 2-methylbenzothiazolium salt 2a and 4,7-dichloroquinolinium methyl sulfate 4a was conducted in water, methanol or ethanol by stirring the reaction mixture at room temperature or by ultrasound irradiation for not more than 40 minutes.

Prolonged sonication causes heating of the samples in the ultrasonic bath and this makes external cooling difficult. In addition, the ultrasound irradiation promotes side reactions and thus leads to slightly lower reaction yields when compared to the room temperature conditions. It is well known that water is one of the most useful green solvents in organic synthesis. The reaction in water as a solvent provided moderate yields (procedures B1 and B2), but the subsequent scale-up of these reactions could be favorable on using intermediates with better water solubility. The best reaction yields for TO-7CI were obtained on using procedure $\mathrm{C} 1$ (Experimental part) with ethanol as the reaction medium. It is worth noting that replacement of the methanol with the environmentally more benign and less harmful ethanol significantly decreases the formation of blue-colored self-condensation byproducts (probably a chromophore constructed from quinolone and quinolinium end groups) and subsequently increases the yield and the purity of the crude products of interest. As mentioned previously, prolonged sonication does not increase the reaction yields, probably due to the promotion of side reactions.

Therefore, the synthesis of the dyes $\mathbf{5 a}-\mathbf{d}$ was achieved according to procedure $\mathrm{C} 1$. In addition, our observation that lower amounts of the blue-colored byproduct were obtained in ethanol solution is probably related to the polarity and the basicity of the medium. We observed that filtration of the final dyes followed by washing the precipitate with ethanol dissolves significant amounts of the byproduct, which was not observed in water or methanol. The subsequent recrystallization of the product from ethanol leads to the isolation of pure (analytical grade) final dyes (TO-7Cl and 5a-d). Furthermore, the use of Hünig's base ( $N, N$-diisopropylethylamine, DIPEA) is essential for the success of the reaction because of the $\mathrm{CH}$-acidity of the benzyl fragment, which otherwise leads to the possibility of side reactions if trimethylamine or other less hindered basic reagents are employed.

\section{Photophysical properties \\ Absorption}

The longest wavelength absorption maxima of the studied dyes are in the region $502-519 \mathrm{~nm}$. The corresponding molar absorptivities are in the range of 70000-92000 L $\cdot \mathrm{mol}^{-1} \cdot \mathrm{cm}^{-1}$ (Figure 1
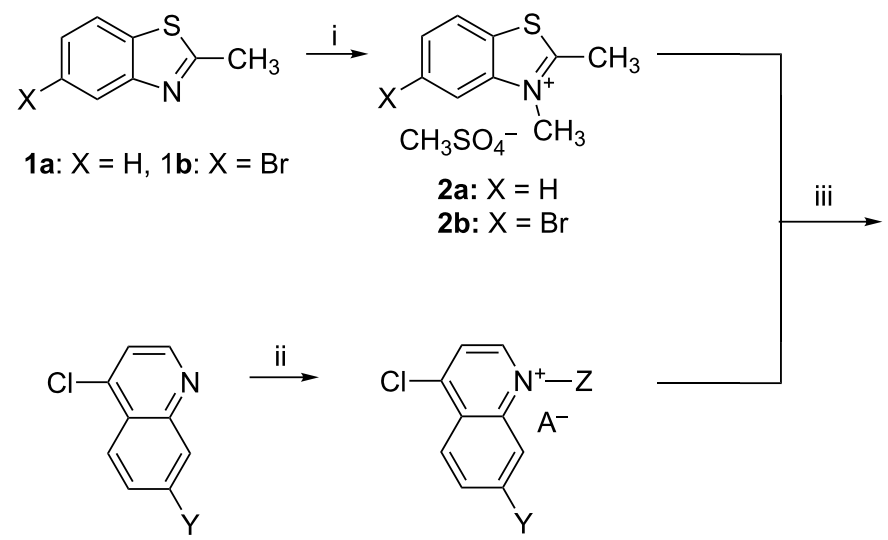

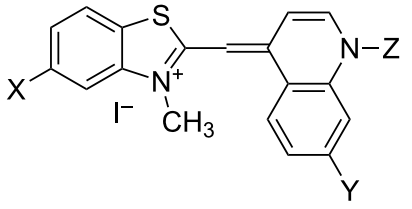

TO-7Cl: $X=\mathrm{H}, Y=\mathrm{Cl}, \mathrm{Z}=\mathrm{CH}_{3}$

5a: $X=\mathrm{H}, Y=\mathrm{Cl}, \mathrm{Z}=\mathrm{CH}_{2} \mathrm{Ph}$

5b: $X=\mathrm{H}, Y=\mathrm{CF}_{3}, \mathrm{CH}_{2} \mathrm{Ph}$

5c: $X=\mathrm{Br}, \mathrm{Y}=\mathrm{Cl}, \mathrm{CH}_{2} \mathrm{Ph}$

5d: $\mathrm{X}=\mathrm{Br}, \mathrm{Y}=\mathrm{CF}_{3}, \mathrm{CH}_{2} \mathrm{Ph}$ 
Table 1: Absorption and emission properties of studied dyes in the absence and presence of dsDNA, calculated fluorescence enhancement factor $\left(l_{f}^{\mathrm{DNA}} / l_{f}^{0}\right)$ and relative fluorescence quantum yield in presence of dsDNA with respect to TO.

\begin{tabular}{|c|c|c|c|c|c|c|c|}
\hline Dye & Chemical structure & $\lambda_{\max }\left(\varepsilon_{\max }\right)^{\mathrm{a}}$ & $\lambda_{\max }^{\mathrm{DNA}}\left(\varepsilon_{\max }^{\mathrm{DNA}}\right)^{\mathrm{b}}$ & $\lambda_{\mathrm{em}}^{\mathrm{c}}$ & $\lambda_{\mathrm{em}}^{\mathrm{DNA}}$ & $I_{f}^{\mathrm{DNA}} / I_{f}^{0}$ & $\Phi_{f} / \Phi_{f}^{T 0 c}$ \\
\hline то & & $502(86100)$ & $510(61100)$ & 549 & 529 & 458 & 1 \\
\hline TO-7Cl & 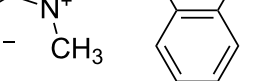 & $509(63000)$ & $520(50500)$ & 550 & 535 & 325 & 0.62 \\
\hline $5 a$ & & $513(91480)$ & $522(89600)$ & 620 & 540 & 454 & 1.28 \\
\hline $5 b$ & $\mathrm{r}_{3}$ & $519(87520)$ & $535(83200)$ & 627 & 550 & 38 & 0.29 \\
\hline $5 c$ & & $513(88400)$ & $520(84900)$ & 600 & 538 & 367 & 0.82 \\
\hline $5 d$ & $\mathrm{CH}_{3}$ & $519(70120)$ & $528(62100)$ & 602 & 550 & 41 & 0.16 \\
\hline
\end{tabular}

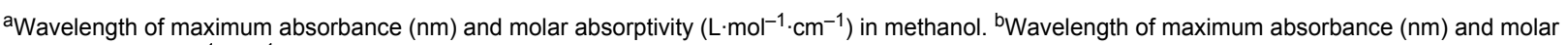
absorptivity $\left(\mathrm{L} \cdot \mathrm{mol}^{-1} \cdot \mathrm{cm}^{-1}\right)$ in TE buffer in presence of dsDNA. CWavelength of maximum fluorescence emission $(\mathrm{nm})$ in absence $\left(\lambda_{\mathrm{em}}\right)$ and presence $\left(\lambda_{\mathrm{em}}^{\mathrm{DNA}}\right)$ of dsDNA. Excitation wavelength in all cases corresponds to the absorption maximum of the dye-dsDNA complex; ${ }^{\mathrm{d}}$ The fluorescence quantum yields in presence of DNA were measured by a gradient method (integrated fluorescence intensity against absorbance) using TO as a reference. All measurements were performed under the same experimental conditions (dsDNA concentration, optical setup, etc.). These are relative values, and should be discussed only in terms of comparison with TO.

and Table 1). The shape of the absorption bands is typical of TO-based chromophores [47-51], with a well pronounced shoulder on the shorter wavelength slope, and it is not sensitive to the type of substituent in the series, thus suggesting similar transition type and geometry of the Franck-Condon excited state.

It can be seen from the results in Table 1 that the replacement of a hydrogen atom with an electron-withdrawing group at the C-7 position in the quinoline moiety of the chromophore leads to a bathochromic shift of the longest wavelength absorption maximum in all new compounds when compared to TO. The presence of a benzyl substituent in compounds 5a-d doesn't have significant effect on the maxima position, slightly shifting the transition further towards lower energies when compared to TO-7CI (in the case of $\mathbf{5 a}$ the red shift is $4 \mathrm{~nm}$ and can be attributed solely to this effect). The bathochromic shift is more pronounced in $\mathbf{5 b}$ and $\mathbf{5 d}$, which bear the stronger electron-withdrawing $\mathrm{CF}_{3}$ group, when compared to the chloro-substituted analogues. It is also noteworthy that the presence of the Br sub- 


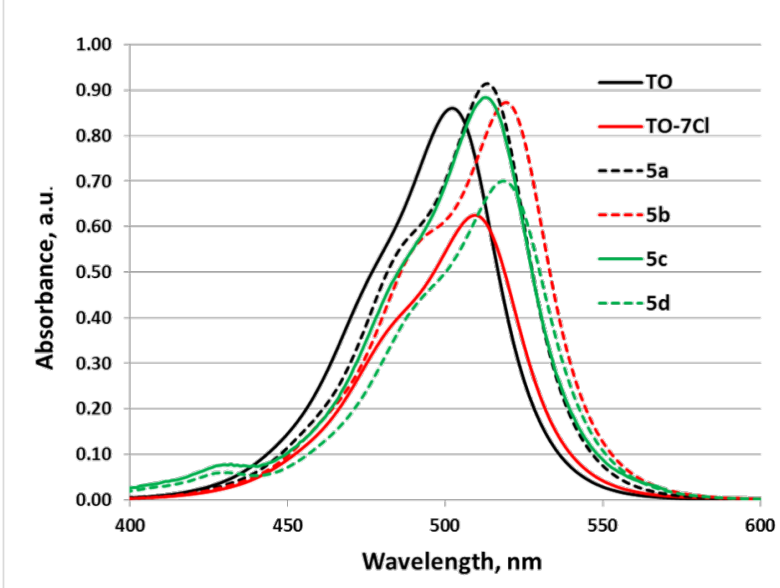

Figure 1: Absorption spectra of the studied compounds in $\mathrm{MeOH}$ $\left(c=1 \times 10^{-5} \mathrm{M}\right)$.

stituent in the $\mathrm{C}-5$ position of the benzothiazole system does not influence the positions of the absorption maxima (cf. $\mathbf{5 a}$ vs $\mathbf{5 c}$ and $\mathbf{5 b}$ vs $\mathbf{5 d}$ ) but does lead to a decrease in the molar absorptivity (up to $20 \%$ from $\mathbf{5 b}$ to $\mathbf{5 d}$ ).

The addition of dsDNA to the dye solutions in TE buffer led to clear bathochromic (in the range 6 to $10 \mathrm{~nm}$ ) and hypohromic shifts and this is illustrated as an example for $\mathbf{5 b}$ in Figure 2. Such a spectral change is generally accepted as evidence for the intercalation of dye molecules into DNA [39-41].

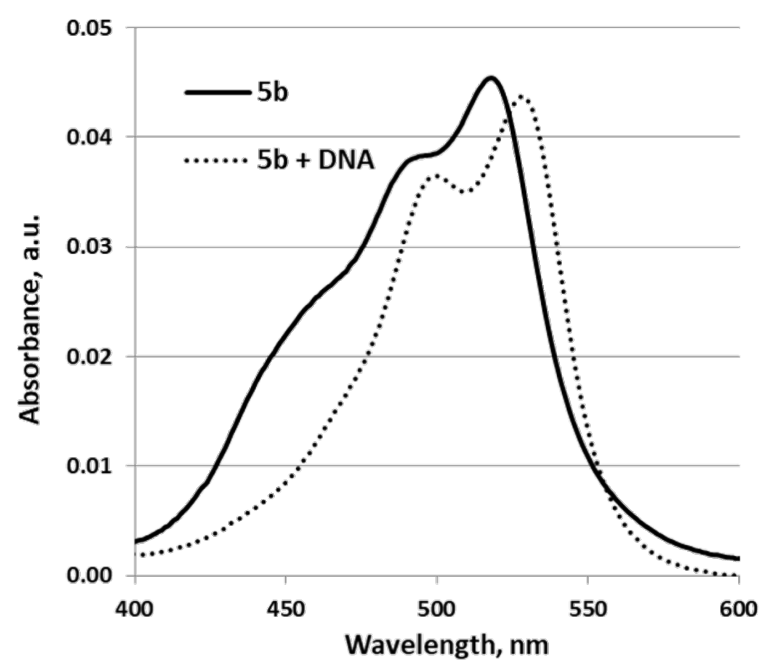

Figure 2: Absorption spectra of dye $5 \mathbf{b}\left(c=5 \times 10^{-7} \mathrm{M}\right)$ in TE buffer, in the absence and presence of dsDNA $\left(c_{\mathrm{DNA}}=1.4 \times 10^{-4} \mathrm{M}\right)$.

\section{Emission}

All dyes have a negligible intrinsic fluorescence in TE buffer, but upon addition of dsDNA a considerable enhancement in fluorescence intensity is observed, even in equimolar ratios of dye/DNA base pairs (Table 1, Figure 3). A strong hypsochromic shift accompanied by a dramatic change in the band shape is observed in the fluorescence maxima of the free dyes in TE buffer upon addition of dsDNA. The fluorescence maxima of dye-dsDNA complexes suggest an increased relative intensity of the $0-0$ transition, which further confirms the intercalation of the ligands in all cases studied.

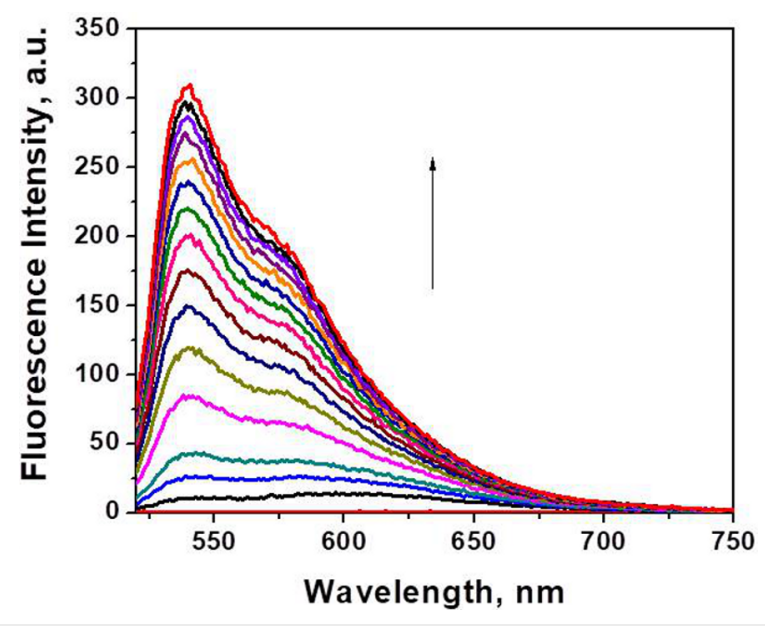

Figure 3: Fluorescence spectra of dye 5a $\left(c=5 \times 10^{-7} \mathrm{M}\right)$ in TE buffer and in the presence of increasing concentrations of dsDNA $\left(c=0-1.4 \times 10^{-4} \mathrm{M}\right)$.

The measured enhancement in the fluorescence intensity upon binding to dsDNA at constant dye concentration $\left(5 \times 10^{-7} \mathrm{M}\right)$ and increasing dsDNA concentration (from 0 to $1.4 \times 10^{-4} \mathrm{M}$ ) is shown in Figure 3. Comparison of the spectroscopic titration data for the series of dyes revealed that $\mathbf{5 a}$ has the lowest initial intrinsic fluorescence on the one hand and the highest fluorescence intensity in presence of dsDNA on the other, which determines the highest fluorescence enhancement factor of 454 for this compound. The latter value (454) is practically identical to that of the reference TO (458), but the fluorescence quantum yield $\Phi_{f} / \Phi_{f}^{T 0}$ measured for $\mathbf{5 a}$ is twice as high as that of TO-7CI, which can be ascribed to the effect of the benzyl substituent. While the chloro substituent itself leads to a decrease of the relative fluorescent quantum yield (62\% for TO-7Cl compared to TO), the benzyl group in $\mathbf{5 a}$ increases it two fold, making 5a almost $30 \%$ brighter than TO under the same conditions (Table 1). In contrast, the dyes bearing trifluoromethyl groups in the 7 position of the quinoline moiety show weak emission even in presence of host molecules. This can be attributed to the strong electron-withdrawing effect of the $\mathrm{CF}_{3}$ group, which change the pathways for deactivation of the excited state [43]. The replacement of the hydrogen atom at the $\mathrm{C}-5$ position in the benzothiazole side of the molecules with a bromo substituent does not have any significant influence on 
the fluorescence of dyes $\mathbf{5 c}$ and $\mathbf{5 d}$, which is similar to its effect on the absorption spectra and is in contrast to the by Armitage et al. observed influence of the replacement of hydrogen with fluorine atom in the benzothiazole ring [43].

\section{Photostability}

The photostability of all dyes in the series was evaluated in acetonitrile with irradiation at $254 \mathrm{~nm}$ with a mercury lamp in equal intervals of two minutes and the results were compared with those obtained for the commercial dye TO. All dyes show similar photostability to TO except for dye $\mathbf{5 c}$, which has a much higher photostability than the commercial dye (Figure 4).

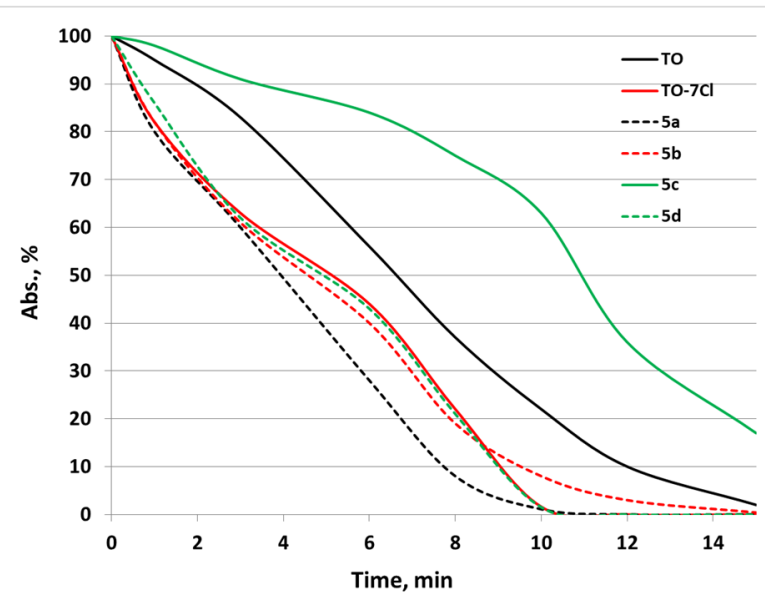

Figure 4: Photostability of dyes TO-7Cl and $5 a-d$ in acetonitrile in the concentration range of $1 \times 10^{-5} \mathrm{M}$.
All dyes from the series demonstrate much higher photostability upon irradiation at $532 \mathrm{~nm}$ by $80 \mathrm{~mW}$ continuous wave frequency doubled DPSS (diode pumped solid state) laser, (Figures S21-S24, Supporting Information File 1).

\section{Computational studies}

Optimized structures of the preferred conformers of the cationic fragments of all dyes with the counterion $\mathrm{I}^{-}$(in the preffered position) are presented in Figure 5 with the respective atom color scheme.

The electronic reorganizations upon excitation were probed using time-dependent density functional theory (TDDFT) calculations. TDPBE0 (time-dependent density functional theory calculations using Perdew-Burke-Ernzerhof exchange-correlation functional) calculations with the $6-311+\mathrm{G}(2 \mathrm{~d}, \mathrm{p})$ basis set for all atoms except I and with the Stuttgart-Dresden SDD effective core potential (ECP) basis set for I predict two bands for all compounds in the range of 400-500 $\mathrm{nm}$. The calculated optical parameters such as the absorption maximum $\left(\lambda_{\max }\right)$, oscillator strength $(f)$ and frontier orbital energy levels are provided in Table 2 . The calculated $\lambda_{\max }$ for the dyes are in the following order: TO $(452 \mathrm{~nm})<$ TO-7Cl $(460 \mathrm{~nm})=\mathbf{5 a}$ $(460 \mathrm{~nm})<\mathbf{5 c}(468 \mathrm{~nm})<\mathbf{5 b}(468 \mathrm{~nm})<\mathbf{5 d}(481 \mathrm{~nm})$. The bathochromic shift of the longest wavelength maximum upon substitution in the quinolone moiety is consistent with the experimentally observed behavior (TO-7CI compared to TO). There is no difference in the predicted maxima for TO-7CI and 5a, so the experimentally observed $4 \mathrm{~nm}$ red shift upon replace-

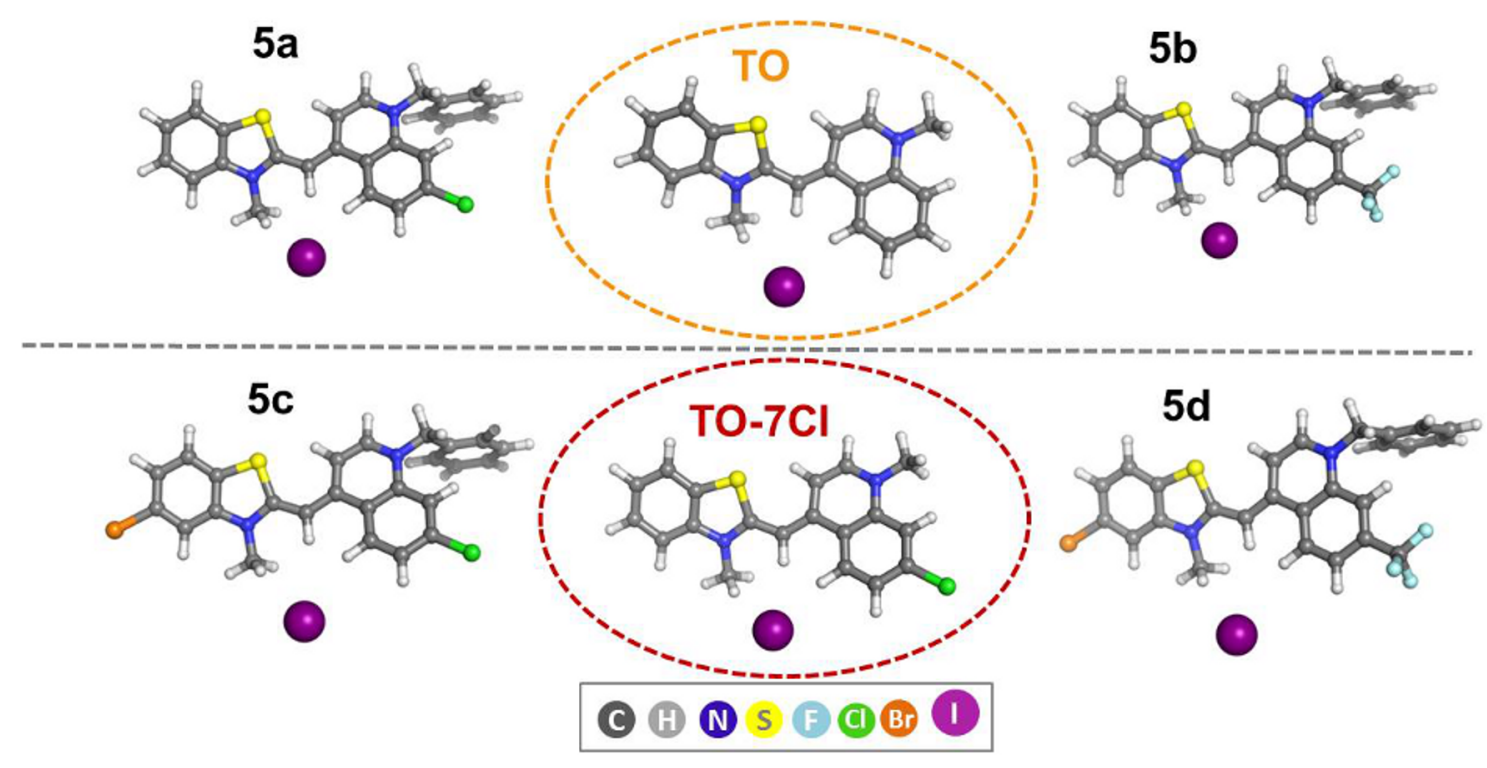

Figure 5: B3LYP optimized structures. 
Table 2: TDDFT/PBE0 excitation energies (eV), wavelengths ( $\mathrm{nm}$ ) (in parentheses), oscillator strength $f$, HOMO and LUMO energies and energy differences (HOMO-LUMO gap) (eV) in methanol for compounds 5a-d, TO and TO-7Cl in methanol.

\begin{tabular}{|c|c|c|c|c|c|c|c|}
\hline \multirow[t]{2}{*}{ Compound } & \multicolumn{2}{|l|}{$\mathrm{HOMO} \rightarrow$ LUMO } & \multicolumn{5}{|l|}{ HOMO-3 $\rightarrow$ LUMO } \\
\hline & $\begin{array}{l}\text { Excitation energy } \\
\text { (wavelength) }\end{array}$ & $f$ & $\begin{array}{l}\text { Excitation energy } \\
\text { (wavelength) }\end{array}$ & $f$ & HOMO & LUMO & HLG \\
\hline TO & $2.74(452)$ & 0.777 & $2.90(428)$ & 0.137 & -5.99 & -2.72 & 3.27 \\
\hline $\mathrm{TO}-7 \mathrm{Cl}$ & $2.70(460)$ & 0.647 & $2.82(439)$ & 0.310 & -6.03 & -2.80 & 3.23 \\
\hline $5 a$ & $2.70(460)$ & 0.595 & $2.83(437)$ & 0.471 & -6.04 & -2.81 & 3.24 \\
\hline $5 b$ & $2.64(470)$ & 0.327 & $2.77(447)$ & 0.703 & -6.08 & -2.90 & 3.18 \\
\hline $5 c$ & $2.65(468)$ & 0.403 & $2.78(446)$ & 0.714 & -6.10 & -2.89 & 3.21 \\
\hline $5 d$ & $2.58(481)$ & 0.218 & $2.73(454)$ & 0.862 & -6.11 & -2.98 & 3.14 \\
\hline
\end{tabular}

ment of the methyl by a benzyl group in the same moiety is not manifested in the theoretical calculations. Theoretically calculated absorption maxima for the couples $\mathbf{5 a} / \mathbf{5 c}$ and $\mathbf{5 b} / \mathbf{5 d}$ differ by $8 \mathrm{~nm}$ and $11 \mathrm{~nm}$, respectively.

The first excited states are determined by HOMO (highest occupied molecular orbital) $\rightarrow$ LUMO (lowest unoccupied molecular orbital) transitions with oscillator strengths in the range of 0.218-0.777. The oscillator strengths of the HOMO-1 and HOMO-2 to LUMO transitions are very small (negligible), so the transitions seen in the absorption spectra in the range of $437-454 \mathrm{~nm}$ are actually HOMO-3 $\rightarrow$ LUMO transitions. The oscillator strengths of HOMO- $3 \rightarrow$ LUMO transitions are in the range of $0.137-0.862$ and for dyes $\mathbf{5 b}-\mathbf{d}$ these transitions are predicted to be more intense than the HOMO-LUMO ones. The HOMO-LUMO gaps are similar and range from $3.14 \mathrm{eV}$ to $3.27 \mathrm{eV}$ for the compounds in methanol. The frontier orbital energy difference for TO is the highest, thus confirming the lower absorption wavelength of TO. In compounds $\mathbf{5 a - d}$ the HOMO was found to be populated over the entire molecular system except for the benzyl fragment and the substituents in position 7 in the quinolone moiety. The LUMO was found to be delocalized over the quinolinium and, to a lesser extent, the benzothiazolium fragments (Figure 6).

The simulated with Doppler broadening with a full width at half-maximum (fwhm) of $0.25 \mathrm{eV}$ and a height proportional to the oscillator strength for each transition spectra (Figure 7) are consistent with those previously reported for cyanine dye monomers [52] and explain the inherent band structure of the monomer's experimental spectrum with one maximum and a shoulder at shorter wavelength.

The bathochromic shift observed for compounds $\mathbf{5 b}$ and $\mathbf{5 d}$ (bearing the stronger electron-withdrawing $\mathrm{CF}_{3}$ group) is not surprising in view of the higher negative electron density of the cationic species located in this fragment (electron density, mapped with electrostatic potential for $\mathbf{5 a}$ and $\mathbf{5 b}$, Figure 8).

\section{Conclusion}

Two novel cationic compounds $\mathbf{4 b}$ and $\mathbf{4 c}$ and four asymmetric monomeric monomethine cyanine dyes containing halogen substituents (5a-d) were synthesized by an environmentally more benign procedure. The properties of the dyes as fluorescence probes for dsDNA detection were investigated and compared with those of the commercial dye TO. In TE buffer solution the dyes from the series have negligible fluorescence themselves, but they form strongly fluorescent dye-dsDNA complexes. Apart from dyes $\mathbf{5 b}$ and $\mathbf{5 d}$, all other dyes demonstrated photophysical properties similar to those of TO. One of the new analogues (5a) shows higher fluorescence in presence of dsDNA in comparison with TO and this property can be used to increase the sensitivity and precision in the appropriate bioanalytical methods. Higher photochemical stability was demonstrated by dye 5c and this had very low fluorescence in the free state. Computational tools were used in an attempt to explain the optical properties of the studied chromophores. The results are encouraging and warrant further investigations into the newly synthesized dyes as DNA fluorogenic binders. A further study of several aspects (including quantum chemical calculations and experimental studies on the DNA binding mechanism) should be carried out on these dyes in order to exploit in details their promising properties.

\section{Experimental \\ Computational details}

The molecular ground state geometries of the cationic fragments of TO, TO-7Cl, 5a-d with I ${ }^{-}$counterions were fully optimized using the Becke three-parameter exchange functional with the Lee-Yang-Parr correction (B3LYP) functional $[53,54]$. We adopted the 6-31+G(d,p) [55-57] basis set for $\mathrm{C}$, $\mathrm{H}, \mathrm{O}, \mathrm{N}, \mathrm{F}, \mathrm{Cl}$, and $\mathrm{Br}$ and the SDD [58] effective core potential (ECP) basis set basis set for I. $C_{1}$ symmetry was assumed for all systems and default convergence criteria were used; local minima were verified by establishing that the Hessians had zero negative eigenvalues. The structures with the counterion were optimized in methanol by means of the integral equation 


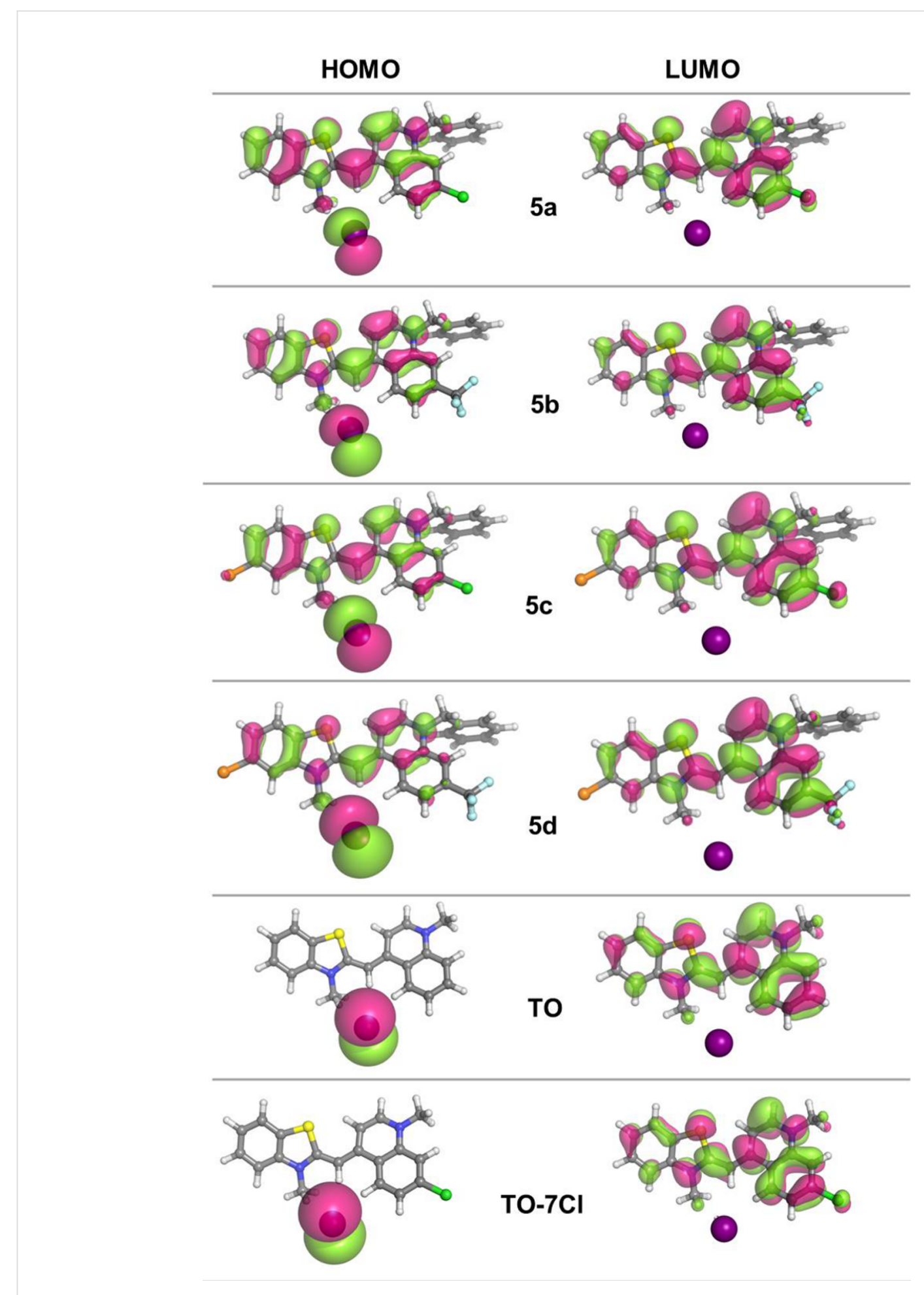

Figure 6: Graphical representation of the frontier orbitals (isodensity plot, isovalue $=0.02$ a.u.).

formalism polarizable continuum model (IEFPCM) [59]. TDPBE0 calculations were performed to compute the 20 lowest excited states of each structure $[6-311+G(2 d, p)$ basis set for all atoms except I]. The effects of surroundings were included in TDDFT calculations. All calculations were performed using Gaussian 09 [60]. The PyMOL molecular graphics system was used to generate the molecular graphics images [61]. 

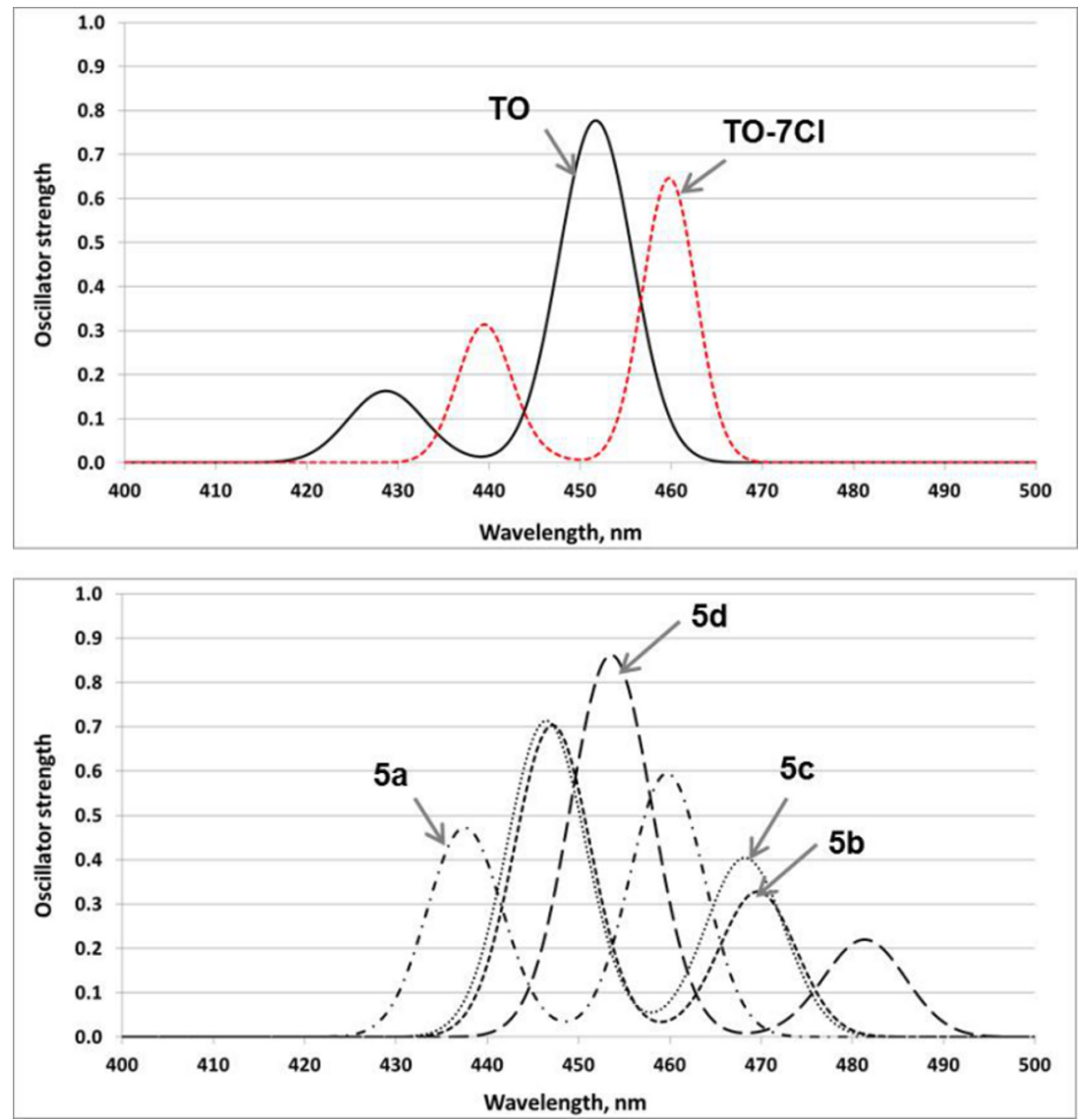

Figure 7: Simulated TDPBE0 spectra in methanol.

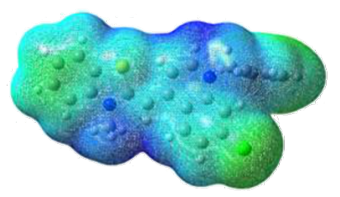

$5 a$

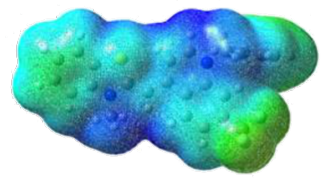

$5 b$
Figure 8: Electron density (isovalue $=0.002$ ) mapped with electrostatic potential (color scheme: green for negative surface map values and blue for the positive ones).

\section{General}

All solvents used in the present work were commercially available (HPLC grade). The starting materials $\mathbf{1 a}, \mathbf{1 b}, \mathbf{3 a}$, and $\mathbf{3 b}$ were commercially available and were used as supplied. Melting points were determined on a Kofler apparatus and are uncorrected. NMR spectra were obtained on a Bruker Avance III $500 \mathrm{DRX} 600 \mathrm{MHz}$ spectrometer in DMSO-d $d_{6}$. UV-vis spectra were measured on a Unicam $530 \mathrm{UV}$-vis spectrophotometer and the fluorescence spectra on a Cary Eclipse fluorescence spectrophotometer (Varian, Australia). The GC-MS anal- ysis was performed on a gas chromatograph HP $6890 \mathrm{GC}$ System Plus coupled to a mass selective detector HP 5973 MSD. The mass selective detector operated in electron impact ionization mode at $70 \mathrm{eV}$ electron energy, the ion source temperature was set to $230^{\circ} \mathrm{C}$, and the quadrupole temperature was $15{ }^{\circ} \mathrm{C}$. The mass scan range was 30-750 amu. Compounds 2 a and 4a were synthesized by methods described in the literature $[51,62]$.

\section{Synthesis}

\section{5-Bromo-2,3-dimethylbenzo[d]thiazolium methyl sulfate $(\mathbf{2 b})$}

5-Bromo-2-methylbenzothiazole (1b, $1 \mathrm{mmol})$ and dimethyl sulfate (DMS, $1.2 \mathrm{mmol}$ ) were mixed in a $50 \mathrm{~mL}$ sealed tube equipped with a magnetic stirrer. The tube was flushed with argon for $5 \mathrm{~min}$ and was sealed. After $2 \mathrm{~h}$ of vigorous stirring at $100{ }^{\circ} \mathrm{C}$ the reaction mixture was cooled to room temperature and methanol $(10 \mathrm{~mL})$ was added. The mixture was heated again until the product had fully dissolved and then cooled down to room temperature. Diethyl ether $(30 \mathrm{~mL})$ was added and the resulting precipitate was filtered off and dried in a desiccator. Yield: 74\%; mp 80-83 ${ }^{\circ} \mathrm{C} ;{ }^{1} \mathrm{H}$ NMR $(500 \mathrm{MHz}$, 
DMSO- $\left.d_{6}\right) \delta 3.16\left(\mathrm{~s}, 3 \mathrm{H}, \mathrm{CH}_{3}\right), 4.18\left(\mathrm{~s}, 3 \mathrm{H}, \mathrm{NCH}_{3}\right), 7.99$ (d, $\left.{ }^{3} J_{\mathrm{HH}}=8.7 \mathrm{~Hz}, 1 \mathrm{H} \mathrm{Ar}-\mathrm{H}\right), 8.36\left(\mathrm{~d},{ }^{3} J_{\mathrm{HH}}=8.7 \mathrm{~Hz}, 1 \mathrm{H}, \mathrm{Ar}-\mathrm{H}\right)$, 8.65 (s, 1H, Ar-H) ppm.

\section{1-Benzyl-4,7-dichloroquinolinium bromide (4b)}

4,7-Dichloroquinoline (3a, $1 \mathrm{mmol}$ ) and benzyl bromide $(1.2 \mathrm{mmol})$ were mixed in a $50 \mathrm{~mL}$ sealed tube equipped with a magnetic stirrer. The tube was flushed with argon for $5 \mathrm{~min}$ and was sealed. After $1 \mathrm{~h}$ of vigorous stirring at $100^{\circ} \mathrm{C}$ the reaction mixture was cooled to room temperature and acetone $(10 \mathrm{~mL})$ was added. The mixture was stirred at room temperature and diethyl ether $(30 \mathrm{~mL})$ was added. The resulting precipitate was filtered off and dried in a desiccator. Yield: 97\%. The compound is hygroscopic and unstable and its chemical structure was confirmed from the structures of the final dyes.

\section{1-Benzyl-4-chloro-7-(trifluoromethyl)quinolinium bro- mide (4c)}

4-Chloro-7-(trifluoromethyl)quinoline (3b, $1 \mathrm{mmol}$ ) and benzyl bromide $(1.2 \mathrm{mmol})$ were mixed in a $50 \mathrm{~mL}$ sealed tube equipped with a magnetic stirrer. The reaction and the work-up were performed in the same way as in the procedure above. Yield: 93\%. The compound is hygroscopic and unstable and its chemical structure was confirmed from the structure of the final dye.

\section{7-Chloro-1-methyl-4-((3-methylbenzo[d]thiazol-} 2(3H)-ylidene)methyl)quinolin-1-ium iodide (TO-7Cl) Procedures A1 and A2: 2,3-Dimethylbenzo[d]thiazolium methyl sulfate (2a, $1 \mathrm{mmol})$ and the appropriate 4,7-dichloro-1methylquinolinium methyl sulfate $(\mathbf{4 a}, 1 \mathrm{mmol})$ were finely ground together in a mortar and the mixture was transferred to a $50 \mathrm{~mL}$ Erlenmeyer flask equipped with a magnetic stirrer and a reflux condenser. Methanol $(15 \mathrm{~mL})$ and $N, N$-diisopropylethylamine (DIPEA, $2.2 \mathrm{mmol}$ ) were added. The reaction mixture was vigorously stirred for $2.5 \mathrm{~h}$ at room temperature (A1) or sonicated (A2) for $40 \mathrm{~min}$. Diethyl ether $(20 \mathrm{~mL})$ was added and the resulting precipitate was filtered off and dissolved in hot methanol $(50 \mathrm{~mL})$. To the hot solution was added saturated aqueous potassium iodide $(5 \mathrm{~mL})$. The mixture was cooled to room temperature the precipitate was filtered off, washed with methanol $(3 \times 10 \mathrm{~mL})$ and diethyl ether $(10 \mathrm{~mL})$ and dried in a vacuum desiccator. The dye was purified by three recrystallizations from methanol. Yield from reaction at room temperature (Procedure A1): $43 \%$ yield from reaction with ultrasound (Procedure A2) 41\%; mp 281-283 ${ }^{\circ} \mathrm{C} ;{ }^{1} \mathrm{H}$ NMR $(500 \mathrm{MHz}$, DMSO$\left.d_{6}\right) \delta 4.01\left(\mathrm{~s}, 3 \mathrm{H}, \mathrm{NCH}_{3}\right), 4.11\left(\mathrm{~s}, 3 \mathrm{H}, \mathrm{NCH}_{3}\right), 6.87(\mathrm{~s}, 1 \mathrm{H}, \mathrm{CH})$ $7.27\left(\mathrm{~d},{ }^{3} J_{\mathrm{HH}}=7.2 \mathrm{~Hz}, 1 \mathrm{H}, \mathrm{Ar}-\mathrm{H}\right), 7.42\left(\mathrm{ddd},{ }^{3} J_{\mathrm{HH}}=7.9 \mathrm{~Hz}\right.$, $\left.{ }^{3} J_{\mathrm{HH}}=7.2 \mathrm{~Hz},{ }^{4} J_{\mathrm{HH}}=0.7 \mathrm{~Hz}, 1 \mathrm{H}, \mathrm{Ar}-\mathrm{H}\right), 7.61\left(\mathrm{ddd},{ }^{3} J_{\mathrm{HH}}=8.4\right.$ $\mathrm{Hz},{ }^{3} J_{\mathrm{HH}}=7.3 \mathrm{~Hz},{ }^{4} J_{\mathrm{HH}}=1.1 \mathrm{~Hz}, 1 \mathrm{H}$, Ar-H $), 7.74-7.78(\mathrm{~m}$, $2 \mathrm{H}, \mathrm{Ar}-\mathrm{H}), 8.04\left(\mathrm{~d},{ }^{3} J_{\mathrm{HH}}=7.2 \mathrm{~Hz}, 1 \mathrm{H}, \mathrm{Ar}-\mathrm{H}\right) ; 8.09(\mathrm{~s}, 1 \mathrm{H}$,
Ar-H), $8.53\left(\mathrm{~d},{ }^{3} J_{\mathrm{HH}}=7.2 \mathrm{~Hz}, 1 \mathrm{H}, \mathrm{Ar}-\mathrm{H}\right), 8.79\left(\mathrm{~d},{ }^{3} J_{\mathrm{HH}}=9.27\right.$ $\mathrm{Hz}, 1 \mathrm{H}, \mathrm{Ar}-\mathrm{H}) \mathrm{ppm} ;{ }^{13} \mathrm{C}$ NMR DEPT $\left(135 \mathrm{MHz}, \mathrm{DMSO}-d_{6}\right) \delta$ $34.5\left(\mathrm{CH}_{3}\right) 42.9\left(\mathrm{CH}_{3}\right), 88.9(\mathrm{CH}), 108.2(\mathrm{CH}), 113.6(\mathrm{CH})$, $118.2(\mathrm{CH}), 123.4(\mathrm{CH}), 125.2(\mathrm{CH}), 127.3(\mathrm{CH}), 128.10(\mathrm{CH})$, $128.70(\mathrm{CH}), 145.8(\mathrm{CH}) \mathrm{ppm}$; IR (nujol) $v_{\max }$ : 1601, 1490, $1468,1367,1321,1203,1160,1115,915,880,765,725,625$ $\mathrm{cm}^{-1}$; GC-MS m/z: $324\left(100 \%,\left[\mathrm{M}^{+}\right]-\mathrm{CH}_{3}\right)$; elemental analysis (\%) for $\mathrm{C}_{19} \mathrm{H}_{16} \mathrm{ClIN}_{2} \mathrm{~S} M_{\mathrm{w}}=466.77$, calcd for $\mathrm{N}, 6.00$; found: 5.57 .

Procedures B1 and B2: 2a (1 $\mathrm{mmol})$ and 4a (1 mmol) were finely ground together and the mixture was transferred to a $50 \mathrm{~mL}$ reaction flask. Distilled water $(15 \mathrm{~mL})$ and $N, N$-diisopropylethylamine (DIPEA, $2.2 \mathrm{mmol}$ ) were added. The reaction mixture was vigorously stirred for $2.5 \mathrm{~h}$ at room temperature (B1) or sonicated for $40 \mathrm{~min}$ (B2). Saturated aqueous potassium iodide $(5 \mathrm{~mL})$ was added and the resulting precipitate was filtered off and washed with methanol $(30 \mathrm{~mL})$, cold water $(30 \mathrm{~mL})$, diethyl ether $(10 \mathrm{~mL})$ and dried in a vacuum desiccator. The dye was purified by two recrystallizations from methanol. Yield B1: 40\%; yield B2: 31\%.

Procedures C1 and C2: $2 \mathrm{a}(1 \mathrm{mmol})$ and $4 \mathrm{a}(1 \mathrm{mmol})$ were finely ground together in a mortar and the mixture was transferred to a $50 \mathrm{~mL}$ Erlenmeyer flask. Ethanol $(15 \mathrm{~mL})$ and $N, N$ diisopropylethylamine (DIPEA, $2.2 \mathrm{mmol}$ ) were added. The reaction mixture was vigorously stirred for $2.5 \mathrm{~h}$ at room temperature $(\mathrm{C} 1)$ or ultra-sonicated for $40 \mathrm{~min}(\mathrm{C} 2)$. Diethyl ether $(20 \mathrm{~mL})$ was added and the resulting precipitate was filtered off and dissolved in boiling ethanol $(60 \mathrm{~mL})$. To the hot solution was added saturated aqueous potassium iodide $(5 \mathrm{~mL})$. The mixture was cooled to room temperature and the resulting precipitate was filtered off and washed with ethanol $(20 \mathrm{~mL})$ and diethyl ether $(20 \mathrm{~mL})$ and dried in a vacuum desiccator. The dye was purified by two recrystallizations from ethanol. Yield $\mathrm{C} 1$ : 67\%; yield C2: $59 \%$.

\section{Synthesis of monocationic monomethine cyanine dyes $\mathbf{5 a - d}$}

2,3-Dimethylbenzo $[d]$ thiazolium methyl sulfate (2a, $1 \mathrm{mmol}$ ) or 5-bromo-2,3-dimethylbenzo[ $d]$ thiazolium methyl sulfate (2b) and the appropriate 4-chloro-substituted quinolinium intermediate $4 \mathbf{a}$ or $\mathbf{4 b}(1 \mathrm{mmol})$ were synthesized and purified according to procedure $\mathrm{C} 1$. The dyes were purified by multiple recrystallizations from ethanol.

2-((1-Benzyl-7-chloroquinolin-4(1H)-ylidene)methyl)-3methylbenzo[d]thiazol-3-ium iodide (5a): Yield 71\%; mp 288-290 ${ }^{\circ} \mathrm{C} ;{ }^{1} \mathrm{H}$ NMR $\left(500 \mathrm{MHz}, \mathrm{DMSO}-d_{6}\right) \delta 4.13(\mathrm{~s}, 3 \mathrm{H}$, $\left.\mathrm{NCH}_{3}\right), 5.94\left(\mathrm{~s}, 2 \mathrm{H}, \mathrm{NCH}_{2} \mathrm{Ph}\right), 7.05(\mathrm{~s}, 1 \mathrm{H}, \mathrm{CH}), 7.33-7.35(\mathrm{~m}$, $3 \mathrm{H}, \mathrm{Ar}-\mathrm{H}), 7.39-7.42(\mathrm{~m}, 2 \mathrm{H}, \mathrm{Ar}-\mathrm{H}), 7.45\left(\mathrm{~d},{ }^{3} J_{\mathrm{HH}}=6.9 \mathrm{~Hz}\right.$, 
$1 \mathrm{H}, \mathrm{Ar}-\mathrm{H}), 7.52\left(\mathrm{dd},{ }^{3} J_{\mathrm{HH}}=7.0 \mathrm{~Hz},{ }^{4} J_{\mathrm{HH}}=0.9 \mathrm{~Hz}, 1 \mathrm{H}, \mathrm{Ar}-\mathrm{H}\right)$, 7.69 (dd, $1 \mathrm{H}, \mathrm{Ar}-\mathrm{H}), 7.91\left(\mathrm{~d},{ }^{3} J_{\mathrm{HH}}=7.5 \mathrm{~Hz}, 1 \mathrm{H}, \mathrm{Ar}-\mathrm{H}\right), 7.92$ $\left(\mathrm{d},{ }^{3} J_{\mathrm{HH}}=8.1 \mathrm{~Hz}, 1 \mathrm{H}, \mathrm{Ar}-\mathrm{H}\right), 8.15\left(\mathrm{~d},{ }^{3} J_{\mathrm{HH}}=7.8 \mathrm{~Hz}, 1 \mathrm{H}\right.$, Ar-H), 8.22 (s, 1H, Ar-H), $8.78\left(\mathrm{~d},{ }^{3} J_{\mathrm{HH}}=6.9 \mathrm{~Hz}, 1 \mathrm{H}, \mathrm{Ar}-\mathrm{H}\right)$, $9.00\left(\mathrm{~d},{ }^{3} J_{\mathrm{HH}}=8.9 \mathrm{~Hz}, 1 \mathrm{H}, \mathrm{Ar}-\mathrm{H}\right) \mathrm{ppm} ;{ }^{13} \mathrm{C}$ NMR DEPT $(135$ $\left.\mathrm{MHz}, \mathrm{DMSO}-d_{6}\right) \delta 33.8,56.0,89.5,107.6,113.2,122.6,123.9$, $124.7,126.1,127.2,127.7,127.9,128.5,134.7,136.5,139.8$, $144.9 \mathrm{ppm}$; IR (nujol) $v_{\max }: 1602,1495,1450,1370,1315$, 1110, 974, 780, 750, $725 \mathrm{~cm}^{-1}$; GC-MS (m/z): $324(100 \%$, $\left.\left[\mathrm{M}^{+}\right]-\mathrm{CH}_{2} \mathrm{Ph}\right)$; elemental analysis $(\%)$ for $\mathrm{C}_{25} \mathrm{H}_{20} \mathrm{ClIN}_{2} \mathrm{~S} M_{\mathrm{W}}$ $=542.86$, calcd for N 5.16; found: 5.53 .

2-((1-Benzyl-7-(trifluoromethyl)quinolin-4(1H)-ylidene)methyl)-3-methylbenzo[d] thiazol-3-ium iodide (5b): Yield 68\%; mp 284-285 ${ }^{\circ} \mathrm{C}$; ${ }^{1} \mathrm{H}$ NMR (500 MHz, DMSO- $\left.d_{6}\right) \delta 4.13$ (s, 3H, $\left.\mathrm{NCH}_{3}\right), 5.94\left(\mathrm{~s}, 2 \mathrm{H}, \mathrm{NCH}_{2} \mathrm{Ph}\right), 7.06(\mathrm{~s}, 1 \mathrm{H}, \mathrm{CH})$, 7.34-7.36 (m, 3H, Ar-H), 7.39-7.43 (m, 2H, Ar-H), 7.49 (d, $\left.1 \mathrm{H},{ }^{3} J_{\mathrm{HH}}=6.5 \mathrm{~Hz}, \mathrm{Ar}-\mathrm{H}\right), 7.52\left(\mathrm{dd}, J_{\mathrm{HH}}^{3}=6.8 \mathrm{~Hz},{ }^{4} J_{\mathrm{HH}}=1.0\right.$ $\mathrm{Hz}, 1 \mathrm{H}, \mathrm{Ar}-\mathrm{H}), 7.69\left(\mathrm{dd}, J^{3} \mathrm{HH}=6.5 \mathrm{~Hz},{ }^{4} J_{\mathrm{HH}}=0.7 \mathrm{~Hz}, 1 \mathrm{H}\right.$, Ar-H), 7.88-7.90 (m, 2H, Ar-H), $7.91\left(\mathrm{~d},{ }^{3} J_{\mathrm{HH}}=7.1 \mathrm{~Hz}, 1 \mathrm{H}\right.$, Ar-H), 8.15 (d, $\left.{ }^{3} J_{\mathrm{HH}}=7.1 \mathrm{~Hz}, 1 \mathrm{H}, \mathrm{Ar}-\mathrm{H}\right), 8.22$ (s, $\left.1 \mathrm{H}, \mathrm{Ar}-\mathrm{H}\right)$, $8.77\left(\mathrm{~d},{ }^{3} J_{\mathrm{HH}}=6.4 \mathrm{~Hz}, 1 \mathrm{H}, \mathrm{Ar}-\mathrm{H}\right), 9.00\left(\mathrm{~d},{ }^{3} J_{\mathrm{HH}}=7.7 \mathrm{~Hz}, 1 \mathrm{H}\right.$, Ar-H) ppm; ${ }^{13} \mathrm{C}$ NMR DEPT (135 MHz, DMSO- $d_{6}$ ) $\delta 34.9$ $\left(\mathrm{CH}_{3}\right) 57.1\left(\mathrm{CH}_{2}\right), 90.6(\mathrm{CH}), 108.7(\mathrm{CH}), 114.3(\mathrm{CH}), 116.4$ $(\mathrm{CH}), 116.5(\mathrm{CH}), 122.4(\mathrm{CH}), 122.3(\mathrm{CH}), 123.6(\mathrm{CH}), 125.8$ $(\mathrm{CH}), 127.3(\mathrm{CH}), 128.3(\mathrm{CH}), 128.8(\mathrm{CH}), 129.0(\mathrm{CH}), 129.6$ $(\mathrm{CH}), 146.0(\mathrm{CH}) \mathrm{ppm}$; IR (nujol) $v_{\max }: 1602,1503,1450$, 1455, 1380, 1310, 1210, 1155, 1120, 1095, 860, 790, 745, 735, 720, $545 \mathrm{~cm}^{-1}$; GC-MS (m/z): $358\left(100 \%,\left[\mathrm{M}^{+}\right]-\mathrm{CH}_{2} \mathrm{Ph}\right)$; elemental analysis (\%) for $\mathrm{C}_{26} \mathrm{H}_{20} \mathrm{~F}_{3} \mathrm{IN}_{2} \mathrm{~S} M_{\mathrm{w}}=576.42$, calcd for $\mathrm{N}, 4.86$; found: 5.20 .

2-((1-Benzyl-7-chloroquinolin-4(1H)-ylidene)methyl)-5bromo-3-methylbenzo[ $d]$ thiazol-3-ium iodide (5c): Yield $72 \%$; mp $=279-281{ }^{\circ} \mathrm{C} ;{ }^{1} \mathrm{H}$ NMR (500 MHz, DMSO- $\left.d_{6}\right) \delta 4.03$ (s, 3H, $\left.\mathrm{NCH}_{3}\right), 5.89$ (s, 2H, $\left.\mathrm{NCH}_{2}\right), 6.94$ (s, 1H, CH), 7.33 (d, $\left.{ }^{3} J_{\mathrm{HH}}=7.4 \mathrm{~Hz}, 2 \mathrm{H}, \mathrm{Ar}-\mathrm{H}\right), 7.36\left(\mathrm{~d},{ }^{3} J_{\mathrm{HH}}=7.2 \mathrm{~Hz}, 1 \mathrm{H}, \mathrm{Ar}-\mathrm{H}\right)$, $7.41\left(\mathrm{dd}, J^{3}{ }_{\mathrm{HH}}=7.5 \mathrm{~Hz},{ }^{3} J_{\mathrm{HH}}=1.6 \mathrm{~Hz}, 2 \mathrm{H}, \mathrm{Ar}-\mathrm{H}\right), 7.43(\mathrm{~s}, 1 \mathrm{H}$, Ar-H), $7.60\left(\mathrm{dd},{ }^{3} J_{\mathrm{HH}}=8.4 \mathrm{~Hz},{ }^{3} J_{\mathrm{HH}}=1.5 \mathrm{~Hz}, 1 \mathrm{H}, \mathrm{Ar}-\mathrm{H}\right), 7.72$ $\left(\mathrm{dd},{ }^{3} J_{\mathrm{HH}}=9.1 \mathrm{~Hz},{ }^{4} J_{\mathrm{HH}}=1.7 \mathrm{~Hz}, 1 \mathrm{H}, \mathrm{Ar}-\mathrm{H}\right), 8.04\left(\mathrm{~d},{ }^{3} J_{\mathrm{HH}}=\right.$ $8.4 \mathrm{~Hz}, 1 \mathrm{H}, \mathrm{Ar}-\mathrm{H}), 8.09$ (d, ${ }^{3} J_{\mathrm{HH}}=8.0 \mathrm{~Hz}, 1 \mathrm{H}, \mathrm{Ar}-\mathrm{H}, 8.093(\mathrm{~d}$, $\left.{ }^{3} J_{\mathrm{HH}}=7.1 \mathrm{~Hz}, 1 \mathrm{H}, \mathrm{Ar}-\mathrm{H}\right), 8.79\left(\mathrm{~d},{ }^{3} J_{\mathrm{HH}}=7.3 \mathrm{~Hz}, 1 \mathrm{H}, \mathrm{Ar}-\mathrm{H}\right)$, $8.83\left(\mathrm{~d},{ }^{3} J_{\mathrm{HH}}=9.2 \mathrm{~Hz}, 1 \mathrm{H}, \mathrm{Ar}-\mathrm{H}\right) \mathrm{ppm} ;{ }^{13} \mathrm{C}$ NMR DEPT $(135$ MHz, DMSO- $\left.d_{6}\right) \delta 34.8\left(\mathrm{CH}_{3}\right), 57.4\left(\mathrm{CH}_{2}\right), 89.9(\mathrm{CH}), 108.8$ $(\mathrm{CH}), 116.6(\mathrm{CH}), 118.3(\mathrm{CH}), 125.0(\mathrm{CH}), 125.1(\mathrm{CH}), 127.2$ $(\mathrm{CH}), 127.5(\mathrm{CH}), 127.9(\mathrm{CH}), 128.6(\mathrm{CH}), 128.8(\mathrm{CH}), 128.8$ $(\mathrm{CH}), 129.6(\mathrm{CH}), 145.9(\mathrm{CH}) \mathrm{ppm}$; IR (nujol) $v_{\max }$ : 1600, $1520,1450,1455,1375,1325,1280,1210,1150,1120,885$, $865,790,725,610,550,401 \mathrm{~cm}^{-1}$; GC-MS $(\mathrm{m} / \mathrm{z}): 480(100 \%$, $\left.\left[\mathrm{M}^{+}\right]-\mathrm{CH}_{2} \mathrm{Ph}\right)$; elemental analysis (\%) for $\mathrm{C}_{25} \mathrm{H}_{19} \mathrm{BrClIN}_{2} \mathrm{~S}$ $M_{\mathrm{W}}=621.76$, calcd for $\mathrm{N}, 4.51$; found: 4.95 .
2-((1-Benzyl-7-(trifluoromethyl)quinolin-4(1H)-ylidene)methyl)-5-bromo-3-methylbenzo[ $d]$ thiazol-3-ium iodide (5d): Yield 77\%; mp $=298{ }^{\circ} \mathrm{C}$ dec.; ${ }^{1} \mathrm{H}$ NMR $(500 \mathrm{MHz}$, DMSO- $\left.d_{6}\right) \delta 4.02\left(\mathrm{~s}, 3 \mathrm{H}, \mathrm{NCH}_{3}\right), 4.09\left(\mathrm{~s}, 2 \mathrm{H}, \mathrm{NCH}_{2}\right), 5.98(\mathrm{~s}$, $1 \mathrm{H}, \mathrm{CH}), 6.71(\mathrm{~s}, 1 \mathrm{H}, \mathrm{Ar}-\mathrm{H}), 7.04(\mathrm{~s}, 1 \mathrm{H}, \mathrm{Ar}-\mathrm{H}), 7.34-7.36(\mathrm{~m}$, $3 \mathrm{H}, \mathrm{Ar}-\mathrm{H}), 7.39-7.42(\mathrm{~m}, 1 \mathrm{H}, \mathrm{Ar}-\mathrm{H}), 7.47\left(\mathrm{~d},{ }^{3} J_{\mathrm{HH}}=7.3 \mathrm{~Hz}\right.$, $1 \mathrm{H}, \mathrm{Ar}-\mathrm{H}), 7.65-7.69(\mathrm{~m}, 1 \mathrm{H}, \mathrm{Ar}-\mathrm{H}), 7.95\left(\mathrm{~d},{ }^{3} J_{\mathrm{HH}}=8.5 \mathrm{~Hz}\right.$, $1 \mathrm{H}, \mathrm{Ar}-\mathrm{H}), 8.08\left(\mathrm{~d},{ }^{3} \mathrm{~J}_{\mathrm{HH}}=8.4 \mathrm{~Hz}, 1 \mathrm{H}, \mathrm{Ar}-\mathrm{H}\right), 8.16-8.19(\mathrm{~m}$, $2 \mathrm{H}, \mathrm{CH}), 8.27(\mathrm{~s}, 1 \mathrm{H}, \mathrm{Ar}-\mathrm{H}), 8.86\left(\mathrm{~d},{ }^{3} J_{\mathrm{HH}}=7.4 \mathrm{~Hz}, 1 \mathrm{H}\right.$, $\mathrm{Ar}-\mathrm{H}), 9.03\left(\mathrm{~d},{ }^{3} J_{\mathrm{HH}}=8.8 \mathrm{~Hz}, 1 \mathrm{H}, \mathrm{Ar}-\mathrm{H}\right) \mathrm{ppm} ;{ }^{13} \mathrm{C} \mathrm{NMR}$ DEPT (135 MHz, DMSO- $\left.d_{6}\right) \delta 35.00\left(\mathrm{CH}_{3}\right), 57.4\left(\mathrm{CH}_{2}\right), 84.1$ $(\mathrm{CH}), 90.7(\mathrm{CH}), 109.3(\mathrm{CH}), 117.0(\mathrm{CH}), 117.3(\mathrm{CH}), 125.2$ $(\mathrm{CH}), 125.6(\mathrm{CH}), 126.1(\mathrm{CH}), 126.4(\mathrm{CH}), 127.3(\mathrm{CH}), 128.1$ $(\mathrm{CH}), 128.9(\mathrm{CH}), 129.6(\mathrm{CH}), 146.4(\mathrm{CH}) \mathrm{ppm}$; IR (nujol) $v_{\max }: 1602,1515,1460,1455,1365,1325,1220,1090,875$, $805,790,740,725,560,530,401 \mathrm{~cm}^{-1}$; GC-MS $(\mathrm{m} / \mathrm{z}): 438$ $\left(100 \%,\left[\mathrm{M}^{+}\right]-\mathrm{CH}_{2} \mathrm{Ph}\right)$; elemental analysis (\%) for $\mathrm{C}_{26} \mathrm{H}_{19} \mathrm{BrF}_{3} \mathrm{IN}_{2} \mathrm{~S} M_{\mathrm{W}}=655.31$, calcd for N, 4.27; found: 4.52 .

\section{Supporting Information}

\section{Supporting Information File 1}

Characterisation data for the compounds: NMR and

GS-MS spectra; validation of the theoretical computations; photostabilities at $532 \mathrm{~nm}$.

[http://www.beilstein-journals.org/bjoc/content/ supplementary/1860-5397-13-283-S1.pdf]

\section{Acknowledgements}

The theoretical calculations were performed on the High Performance Computing Cluster installed at IOCCP - BAS with the financial support of the Bulgarian Scientific Fund under Project "MADARA" (RNF01/0110, contract N_DO02-52/2008). The work was supported by the programs: "Ayudas para Estancias de Científicos y Tecnólogos Extranjeros en la Universidad de Alcalá", "Materials Networking" (Twining-692146), Projects from the Spanish Ministerio de Economía y Competitividad (MINECO): CTQ2016-80600-P, CTQ2014-52488-R, and Project from the University of Alcalá CCG2016/EXP-076.

\section{ORCID ${ }^{\circledR}$ iDs}

Aleksey A. Vasilev - https://orcid.org/0000-0003-2199-5644 Stanimir S. Stoyanov - https://orcid.org/0000-0002-7830-1538 Silvia E. Angelova - https://orcid.org/0000-0003-4717-8028

\section{References}

1. Lee, L. G.; Chen, C.-H.; Chiu, L. A. Cytometry 1986, 7, 508-517. doi:10.1002/cyto.990070603

2. Lee, L. G.; Chen, C.-H. Detection of reticulocytes, RNA or DNA. U.S. Patent US4883867, Nov 28, 1989. 
3. Kurutos, A.; Ryzhova, O.; Trusova, V.; Tarabara, U.; Gorbenko, G.; Gadjev, N.; Deligeorgiev, T. Dyes Pigm. 2016, 130, 122-128. doi:10.1016/j.dyepig.2016.03.021

4. Crnolatac, I.; Rogan, I.; Majić, B.; Tomić, S.; Deligeorgiev, T.; Horvat, G.; Makuc, D.; Plavec, J.; Pescitelli, G.; Piantanida, I. Anal. Chim. Acta 2016, 940, 128-135. doi:10.1016/j.aca.2016.08.021

5. Carlsson, C.; Larsson, A.; Jonsson, M.; Albinsson, B.; Norden, B. J. Phys. Chem. 1994, 98, 10313-10321. doi:10.1021/j100091a055

6. Netzel, T. L.; Nafisi, K.; Zhao, M.; Lenhard, J. R.; Johnson, I. J. Phys. Chem. 1995, 99, 17936-17947. doi:10.1021/j100051a019

7. Karlsson, H. J.; Bergqvist, M. H.; Lincoln, P.; Westman, G. Bioorg. Med. Chem. 2004, 12, 2369-2384. doi:10.1016/j.bmc.2004.02.006

8. Nygren, J.; Svanvik, N.; Kubista, M. Biopolymers 1998, 46, 39-51. doi:10.1002/(SICI)1097-0282(199807)46:1<39::AID-BIP4>3.0.CO;2-Z

9. Wang, Y.; Yang, J.; Wu, X.; Li, L.; Sun, S.; Su, B.; Zhao, Z. Anal. Lett. 2003, 36, 2063-2094. doi:10.1081/AL-120023702

10. Patonay, G.; Salon, J.; Sowell, J.; Strekowski, L. Molecules 2004, 9 , 40-49. doi:10.3390/90300040

11. Bohländer, P. R.; Wagenknecht, H.-A. Methods Appl. Fluoresc. 2015, 3, 044003. doi:10.1088/2050-6120/3/4/044003

12. Zhang, X. H.; Liu, Q.; Shi, H. J.; Wang, L. Y.; Fu, Y. L.; Wei, X. C.; Yang, L. F. Dyes Pigm. 2014, 100, 232-240. doi:10.1016/j.dyepig.2013.09.011

13. Hirons, G. T.; Fawcett, J. J.; Crissman, H. A. Cytometry 1994, 15, 129-140. doi:10.1002/cyto.990150206

14. Yan, X.; Grace, W. K.; Yoshida, T. M.; Habbersett, R. C.; Velappan, N.; Jett, J. H.; Keller, R. A.; Marrone, B. L. Anal. Chem. 1999, 71, 5470-5480. doi:10.1021/ac990780y

15. Hammond, M. L.; Jett, J. H.; Keller, R. A.; Marrone, B. L.; Martin, J. C. DNA fragment sizing and sorting by laser-induced fluorescence. U.S. Patent US5558998 A, Sept 24, 1996.

16. Svanvik, N.; Westman, G.; Wang, D.; Kubista, M. Anal. Biochem. 2000, 281, 26-35. doi:10.1006/abio.2000.4534

17. Ishiguro, T.; Saitoh, J.; Yawata, H.; Otsuka, M.; Inoue, T.; Sugiura, Y. Nucleic Acids Res. 1996, 24, 4992-4997. doi:10.1093/nar/24.24.4992

18. Bethge, L.; Jarikote, D. V.; Seitz, O. Bioorg. Med. Chem. 2008, 16, 114-125. doi:10.1016/j.bmc.2006.12.044

19. Bethge, L.; Seitz, O. XIVth Symposium on Chemistry of Nucleic Acid Components; Collection Symposium Series Český Krumlov, Vol. 10; 2008; pp 317-319. doi:10.1135/css200810317

20. Hövelmann, F.; Gaspar, I.; Ephrussi, A.; Seitz, O. J. Am. Chem. Soc. 2013, 135, 19025-19032. doi:10.1021/ja410674h

21. Hövelmann, F.; Seitz, O. Acc. Chem. Res. 2016, 49, 714-723. doi:10.1021/acs.accounts.5b00546

22. Arndt, S.; Walter, H.-K.; Wagenknecht, H.-A. J. Visualized Exp. 2016, 113, e54121. doi:10.3791/54121

23. Berndl, S.; Dimitrov, S. D.; Menacher, F.; Fiebig, T.; Wagenknecht, H.-A. Chem. - Eur. J. 2016, 22, 2386-2395. doi:10.1002/chem.201503849

24. Gurrieri, S.; Wells, K. S.; Johnson, I. D.; Bustamante, C. Anal. Biochem. 1997, 249, 44-53. doi:10.1006/abio.1997.2102

25. Nyberg, L.; Persson, F.; Åckerman, B.; Westerlund, F. Nucleic Acids Res. 2013, 41, e184. doi:10.1093/nar/gkt755

26. Tang, W.; Zhou, H.; Li, W. PLoS One 2015, 10, e0144422. doi:10.1371/journal.pone.0144422

27. Mackay, I. M.; Mackay, J. F.; Nissen, M. D.; Sloots, T. P. In Real-Time PCR in Microbiology: From Diagnosis to Characterization; Mackay, I. M., Ed.; Caister Academic Press, 2007.
28. Bengtsson, M.; Karlsson, H. J.; Westman, G.; Kubista, M. Nucleic Acids Res. 2003, 31, e45. doi:10.1093/nar/gng045

29. Carreon, J. R.; Mahon, K. P., Jr.; Kelley, S. O. Org. Lett. 2004, 6, 517-519. doi:10.1021/ol0362818

30. Babendure, J.; Liddell, P. A.; Bash, R.; LoVullo, D.; Schiefer, T. K.; Williams, M.; Daniel, D. C.; Thompson, M.; Taguchi, A. K. W.; Lohr, D.; Woodbury, N. W. Anal. Biochem. 2003, 317, 1-11. doi:10.1016/S0003-2697(03)00085-X

31. Svanvik, N.; Nygren, J.; Westman, G.; Kubista, M. J. Am. Chem. Soc. 2001, 123, 803-809. doi:10.1021/ja002294u

32. Okamoto, A. In Modified Nucleic Acids; Nakatani, K.; Tor, Y., Eds.; Springer International Publishing: Cham, 2016; pp 63-81. doi:10.1007/978-3-319-27111-8_3

33. Wang, X.; Krull, U. J. Bioorg. Med. Chem. Lett. 2005, 15, 1725-1729. doi:10.1016/j.bmcl.2005.01.030

34. Wang, X.; Krull, U. J. Anal. Chim. Acta 2002, 470, 57-70. doi:10.1016/S0003-2670(02)00671-2

35. Algar, W. R.; Massey, M.; Krull, U. J. J. Fluoresc. 2006, 16, 555-567. doi:10.1007/s10895-006-0091-y

36. Steinmeyer, J.; Rönicke, F.; Schepers, U.; Wagenknecht, H.-A ChemistryOpen 2017, 6, 514-518. doi:10.1002/open.201700059

37. Ji, H. P.; Lau, B. T. C.; Miotke, L. Quantification of mutant alleles and copy number variation using digital pcr with nonspecific dna-binding dyes. WO Patent WO2015095225A1, June 25, 2015.

38. Doan, P. H.; Pitter, D. R. G.; Kocher, A.; Wilson, J. N.; Goodson, T., III. J. Am. Chem. Soc. 2015, 137, 9198-9201. doi:10.1021/jacs.5b02674

39. Crnolatac, I.; Tumir, L.-M.; Lesev, N. Y.; Vasilev, A. A.; Deligeorgiev, T. G.; Mišković, K.; Glavaš-Obrovac, L.; Vugrek, O.; Piantanida, I. ChemMedChem 2013, 8, 1093-1103. doi:10.1002/cmdc.201300085

40. Zarkov, A.; Vasilev, A.; Deligeorgiev, T.; Stoynov, S.; Nedelcheva-Veleva, M. Mol. Imaging 2013, 12, 90-99.

41. Vasilev, A.; Lesev, N.; Dimitrova, S.; Nedelcheva-Veleva, M.; Stoynov, S.; Angelova, S. Color. Technol. 2015, 131, 94-103. doi:10.1111/cote. 12133

42. Renikuntla, B. R.; Rose, H. C.; Eldo, J.; Waggoner, A. S.; Armitage, B. A. Org. Lett. 2004, 6, 909-912. doi:10.1021/ol036081w

43. Silva, G. L.; Ediz, V.; Yaron, D.; Armitage, B. A. J. Am. Chem. Soc. 2007, 129, 5710-5718. doi:10.1021/ja070025z

44. Brooker, L. G. S.; Keyes, G. H.; Williams, W. W. J. Am. Chem. Soc. 1942, 64, 199-210. doi:10.1021/ja01254a002

45. Beilenson, B.; Hamer, F. M. J. Chem. Soc. 1939, 143-151. doi:10.1039/jr9390000143

46. Sexton, W. A. J. Chem. Soc. 1939, 470-473. doi:10.1039/JR9390000470

47. Anastas, P. T.; Warner, J. Green Chemistry: Theory and Practice; Oxford University Press: Oxford, 1998.

48. Anastas, P. T.; Williamson, T. C. Green Chemistry: Frontiers in Benign Chemical Synthesis and Processes; Oxford University Press: New York, 1998.

49. Anastas, P. T.; Kirchhoff, M. M. Acc. Chem. Res. 2002, 35, 686-694. doi:10.1021/ar010065m

50. Deligeorgiev, T.; Vasilev, A.; Tsvetkova, T.; Drexhage, K.-H. Dyes Pigm. 2007, 75, 658-663. doi:10.1016/j.dyepig.2006.07.012

51. Vasilev, A.; Deligeorgiev, T.; Kaloyanova, S.; Stoyanov, S.; Maximova, V.; Vaquero, J. J.; Alvarez-Builla, J. Color. Technol. 2011, 127, 69-74. doi:10.1111/j.1478-4408.2010.00280.x

52. West, W.; Pearce, S. J. Phys. Chem. 1965, 69, 1894-1903. doi:10.1021/j100890a019 
53. Becke, A. D. J. Chem. Phys. 1993, 98, 5648-5652. doi:10.1063/1.464913

54. Lee, C.; Yang, W.; Parr, R. G.

Phys. Rev. B: Condens. Matter Mater. Phys. 1988, 37, 785-789. doi:10.1103/PhysRevB.37.785

55. Hehre, W. J.; Ditchfield, R.; Pople, J. A. J. Chem. Phys. 1972, 56, 2257-2261. doi:10.1063/1.1677527

56. Clark, T.; Chandrasekhar, J.; Spitznagel, G. W.; Von Ragué Schleyer, P. J. Comput. Chem. 1983, 4, 294-301. doi:10.1002/jcc.540040303

57. Frisch, M. J.; Pople, J. A.; Binkley, J. S. J. Chem. Phys. 1984, 80 3265-3269. doi:10.1063/1.447079

58. Igel-Mann, G.; Stoll, H.; Preuss, H. Mol. Phys. 1988, 65, 1321-1328. doi:10.1080/00268978800101811

59. Tomasi, J.; Mennucci, B.; Cammi, R. Chem. Rev. 2005, 105, 2999-3094. doi:10.1021/cr9904009

60. Gaussian 09, Revision D.01; Gaussian, Inc.: Wallingford, CT, 2009 61. PyMOL, Version 1.8; Schrödinger, LLC

62. Deligeorgiev, T.; Vasilev, A.; Drexhage, K.-H. Dyes Pigm. 2007, 74, 320-328. doi:10.1016/j.dyepig.2006.02.010

\section{License and Terms}

This is an Open Access article under the terms of the Creative Commons Attribution License (http://creativecommons.org/licenses/by/4.0), which permits unrestricted use, distribution, and reproduction in any medium, provided the original work is properly cited.

The license is subject to the Beilstein Journal of Organic Chemistry terms and conditions:

(http://www.beilstein-journals.org/bjoc)

The definitive version of this article is the electronic one which can be found at: doi:10.3762/bjoc. 13.283 